\title{
Digestible Valine Requirements in Low-Protein Diets for Broilers Chicks
}

\section{-Author(s)}

\author{
Nascimento GR' \\ Murakami AE" \\ Ospina-Rojas IC" \\ Diaz-Vargas M" \\ Picoli KPII \\ Garcia RGIII
}

Universidade Federal Rural de Pernambuco (UFRPE), Recife, PE, Brasil. nascimentogr@ gmail.com.

" Universidade Estadual de Maringá (UEM), Maringá, PR, Brasil.

III Universidade Federal da Grande Dourados (UFGD), Dourados, MS, Brasil.

\section{-Mail Address}

Corresponding author e-mail address Guilherme Rodrigues do Nascimento

National Program of Post-Doctorate - PNPD/ CAPES. Department of animal science, UFRPE, Recife, Brazil.

Tel: (5581) 996432287

Email: nascimentogr@gmail.com

\section{EKeywords}

Amino acid, branched-chain, fiber diameter.

\section{ABSTRACT}

Three experiments were carried out to evaluate the levels of digestible valine in diets with reduced crude protein on the performance, carcass yield and muscle fiber diameter of male broilers during the pre-starter ( 1 to $8 \mathrm{~d}$ of age), starter (9 to $21 \mathrm{~d}$ of age) and grower phases (21 to $42 \mathrm{~d}$ of age). A total of 1,080 chickens in the pre-starter phase, 900 in the starter phase and 864 in the grower phase were distributed in a completely randomized design with six treatments, consisting of a control positive diet $(\mathrm{C}+)$ and diets with 2 percentage points (p.p.) reduction of crude protein level and five graded levels of digestible valine (Val), with six replicates of 30, 25 and 24 birds per experimental unit, respectively. The recommended level of TID Val in the low-protein diets for broilers in the pre-starter, starter and grower stages were $1.028 ; 0.905$ and $0.789 \%$, respectively. The reduction of 2 percentage points of the crude protein level in diets based on corn and soybean meal impaired $(p \leq 0.05)$ the feed conversion ratio in the starter and grower stages. Likewise, the reduced-protein diets decreased $(p \leq 0.05)$ muscle fiber diameter, but did not affect ( $p>0.05)$ carcass and parts yields, or abdominal fat percentage at 42 days.

\section{INTRODUCTION}

Poultry production is as one of most important agribusinesses in Brazil. The continuous progress of this industry is a result of advances in scientific knowledge and technologies, such as nutrition, which is essential to obtain the best poultry performance (Campos et al., 2012).

Changes in the international market related to the ban of the inclusion of animal products in animal feeds, and feed formulation manipulations aiming at reducing the excretion of potential pollutants, such as nitrogen, have led to formulation of broiler diets with reduced protein content. Reduced-protein diets may change amino acid availability and promote negative interactions among amino acids, resulting in poor performance. One of such interactions is that among valine, isoleucine, and leucine, are branched-chain amino acids (BCAA). Corn and soybean meal proteins contain more leucine than valine and isoleucine, which may increase the requirement of the last two amino acids in broiler diets, particularly during the grower phase (Berres et al., 2010) and when reduced-protein diets are fed to broilers. Valine is more susceptible than isoleucine to the increase in dietary leucine levels (D'Mello, 2003), and it is considered the fourth limiting amino acid in broilers diets based on corn and soybean meal with no inclusion of animal feedstuffs (Thornton et al., 2006; Tavernari et al., 2013). Valine requirements increase with broiler age, when dietary crude protein content is reduced (Corzo et al., 2007; Corzo et al., 2010; Duarte et al., 2014). 
Nascimento GR, Murakami AE, Ospina-Rojas IC, Diaz-Vargas M, Picoli KP, Garcia RG
Digestible Valine Requirements in Low-Protein Diets for Broilers Chicks
The objective of this experiment was to evaluate the effects of different digestible valine levels in prestarter, starter, and grower diets with reduced crude protein on the performance, carcass yield, and muscle fiber diameter of broilers.

\section{MATERIAL AND METHODS}

All procedures used in this study were approved by the Ethics and Research Committee of State University of Maringá, under protocol CEUA/UEM 1361/2014.

Three experiments were carried out in the poultry sector of the Experimental Farm of Iguatemi of the State University of Maringá. In the three experiments, all birds were reared in floor pens $(2.0 \times 1.0 \mathrm{~m})$ with fresh wood shavings as litter. Each pen was equipped with one tube feeder and six nipple drinkers. Temperature was maintained at $32^{\circ} \mathrm{C}$ at placement and was gradually reduced to ensure comfort using a heater controlled by a thermostat, exhaustion fans, and cool cells. Ventilation was accomplished by negative air pressure. The lighting program throughout the study consisted of $23 \mathrm{~h}$ of light and $1 \mathrm{~h}$ of dark. Feed and water were available to the birds ad libitum.

In experiment I, 1,080 one-day-old male Cobb 700 broilers, with $50.66 \mathrm{~g} \pm 0.89$ average initial body weight, were distributed according to a completely randomized design, into six treatments with six replicates of 30 birds per pen (density of $0.76 \mathrm{~kg} \cdot \mathrm{m}^{-2}$ ). The treatments consisted of a control positive $(C+)$ diet based on corn and soybean meal, containing $22 \%$ crude protein, as recommended by Rostagno et al. (2011), and five different levels of digestible valine $(0.866,0.935,1.009,1.084$, and $1.158 \%)$ in the diet formulated with $2 \%$ reduction of crude protein (CP) level. The dietary levels of valine were obtained by supplementing the reduced-protein diet with L-valine at the expense of inert filler, kaolin. The digestible valine levels (TID Val) corresponded the recommendations for the pre-starter diet (1.009\% TID Val), according to Rostagno et al. (2011), and two levels below and two levels above of that recommendation.

In experiment II, 900 9-d-old male Cobb 700 broilers, with $209.45 \mathrm{~g} \pm 2.93$ average body weight, were distributed according to a completely randomized design into six treatments with six replicates of 25 birds per pen (density of $2.618 \mathrm{~kg} \cdot \mathrm{m}^{-2}$ ). The birds were fed a conventional diet from one to eight days of age, prior to the experimental period. The treatments consisted of a control positive $(\mathrm{C}+)$ diet based on corn and soybean meal, containing $20 \%$ crude protein, as recommended by Rostagno et al. (2011), and five different levels of digestible valine $(0.755 ; 0.830 ; 0.904 ; 0.979$ and $1.053 \%$ ) in the diet formulated with $2 \%$ reduction of crude protein (CP) level.

In experiment III, 864 21-d-old male Cobb 700 broilers, with $924 \mathrm{~g} \pm 18.6$ average body weight, were used. The reduction in bird number in order to maintain rearing density $\left(9.24 \mathrm{~kg} \cdot \mathrm{m}^{-2}\right)$. Birds were distributed according to a completely randomized design into six treatments with six replicates of 20 birds each per pen. The birds were fed a conventional diet from one to 21 days of age, prior to the experimental period. The treatments consisted of a control positive $(\mathrm{C}+)$ diet based on corn and soybean meal, containing $18.5 \%$ crude protein, as recommended by Rostagno et al. (2011), and five different levels of digestible valine $(0.695 ; 0.755 ; 0.815 ; 0.875$ and $0.935 \%)$ in the diet formulated with $2 \%$ reduction of crude protein $(C P)$ level.

The positive control $\left(C_{+}\right)$diets and the basal diet with reduced crude protein $(C P)$ levels are shown in Table 1.

Broilers and feed were weighed at the beginning and end of each experimental period ( 1 to $8 d, 9$ to 21 $\mathrm{d}$ and 21 to $42 \mathrm{~d}$ of age) for performance evaluation (feed intake, weight gain, and feed conversion ratio). At 42 days of age, at the end of the grower period (Experiment III), carcass yield and muscle fiber diameter were determined.

Two birds per experimental unit (12 birds per treatment), with the average body weight of the experimental unit $( \pm 5 \%)$, were selected and fasted for 06 hours. Birds were sacrificed by intravenous administration of sodium thiopental $(70 \mathrm{mg} / \mathrm{kg}$ ), followed by section of the jugular vein. Carcasses were plucked, eviscerated, and weighed to determine carcass yield, calculated as carcass weight relative to live body weight. Breast, leg (thigh and drumstick), back, and wing yields were calculated as the weight of these parts relative to eviscerated carcass weight. The abdominal fat surrounding the cloaca, gizzard, proventriculus, and adjacent abdominal muscles was removed, weighed, and expressed as a percentage of eviscerated carcass weight.

Two other birds per experimental unit (12 birds per treatment), with the average body weight of the experimental unit $( \pm 5 \%)$, were then selected to measure the diameter of the muscle fibers of the pectoralis major. Birds were sacrificed as described above. A tissue block of the pectoralis major muscle $(1 \mathrm{~cm} \times 1 \mathrm{~cm} \times 2.5 \mathrm{~cm})$ of two broilers per pen was cross-sectioned perpendicularly to the direction of 
Table 1 - Ingredients and calculated composition of the control diet $\left(C_{+}\right)$and of the reduced-protein diet (RP) fed during pre-starter, starter, and grower phases.

\begin{tabular}{|c|c|c|c|c|c|c|}
\hline \multirow{2}{*}{ Ingredients } & \multicolumn{2}{|c|}{ Pre-starter } & \multicolumn{2}{|c|}{ Starter } & \multicolumn{2}{|c|}{ Grower } \\
\hline & $\mathrm{C}+$ & $\mathrm{RP}$ & $\mathrm{C}+$ & $\mathrm{RP}$ & $\mathrm{C}+$ & $\mathrm{RP}$ \\
\hline Corn & 55.15 & 64.12 & 59.08 & 69.44 & 64.98 & 72.53 \\
\hline Soybean meal $45 \%$ & 38.04 & 29.17 & 34.77 & 24.68 & 28.60 & 21.01 \\
\hline Soybean oil & 2.18 & 0.60 & 2.20 & 0.38 & 2.92 & 1.62 \\
\hline Limestone & 0.96 & 0.96 & 0.97 & 0.97 & 0.86 & 0.86 \\
\hline Dicalcium phosphate & 1.91 & 1.99 & 1.51 & 1.59 & 1.18 & 1.25 \\
\hline Salt & 0.50 & 0.50 & 0.48 & 0.48 & 0.45 & 0.45 \\
\hline Vit.+ Min. supplement 1,2 & $0.40^{1}$ & $0.40^{1}$ & $0.40^{1}$ & $0.40^{1}$ & $0.40^{2}$ & $0.40^{2}$ \\
\hline DL-Methionine 99\% & 0.361 & 0.437 & 0.287 & 0.373 & 0.255 & 0.321 \\
\hline L-Lysine $\mathrm{HCl} 78,5 \%$ & 0.294 & 0.566 & 0.217 & 0.526 & 0.240 & 0.473 \\
\hline L-Threonine 98\% & 0.108 & 0.225 & 0.058 & 0.191 & 0.055 & 0.156 \\
\hline L-Arginine 99\% & 0.022 & 0.278 & - & 0.252 & 0.038 & 0.217 \\
\hline L-Tryptophan 99\% & - & 0.023 & - & 0.024 & - & 0.043 \\
\hline L-Valine $98 \%$ & 0.079 & - & 0.024 & - & 0.038 & - \\
\hline L-Isoleucine $98 \%$ & - & 0.168 & - & 0.150 & 0.028 & 0.136 \\
\hline Inert material $^{3}$ & - & 0.560 & - & 0.540 & - & 0.530 \\
\hline \multicolumn{7}{|l|}{ Calculated Values } \\
\hline Crude Protein, \% & 22.0 & 20.0 & 20.0 & 18.0 & 18.5 & 16.5 \\
\hline Metabolizable energy, Mcal/kg & 2950 & 2950 & 3000 & 3000 & 3125 & 3125 \\
\hline Calcium, \% & 0.92 & 0.92 & 0.82 & 0.82 & 0.69 & 0.69 \\
\hline Available phosphorus, \% & 0.47 & 0.47 & 0.391 & 0.391 & 0.320 & 0.320 \\
\hline Chlorine, \% & 0.406 & 0.458 & 0.388 & 0.441 & 0.367 & 0.367 \\
\hline Sodium, \% & 0.217 & 0.217 & 0.210 & 0.210 & 0.198 & 0.198 \\
\hline Potassium, \% & 0.856 & 0.719 & 0.788 & 0.653 & 0.711 & 0.595 \\
\hline TID met+cys, \% & 0.944 & 0.944 & 0.846 & 0.846 & 0.762 & 0.762 \\
\hline TID Lysine, \% & 1.310 & 1.310 & 1.174 & 1.174 & 1.044 & 1.044 \\
\hline TID Threonine, \% & 0.852 & 0.852 & 0.763 & 0.763 & 0.679 & 0.679 \\
\hline TID Arginine, $\%$ & 1.415 & 1.415 & 1.268 & 1.268 & 1.268 & 1.268 \\
\hline TID Valine, \% & 1.009 & - & 0.904 & - & 0.815 & 0.695 \\
\hline TID Tryptophan,\% & 0.248 & 0.223 & 0.224 & 0.224 & 0.198 & 0.198 \\
\hline TID Isoleucine, \% & 0.878 & 0.878 & 0.787 & 0.787 & 0.710 & 0.710 \\
\hline TID Leucine, \% & 1.709 & 1.508 & 1.610 & 1.401 & 1.497 & 1.323 \\
\hline TID Phenylalanine, \% & 0.928 & 0.854 & 0.936 & 0.770 & 0.845 & 0.705 \\
\hline TID Histidine, $\%$ & 0.498 & 0.461 & 0.502 & 0.420 & 0.457 & 0.388 \\
\hline
\end{tabular}

1 - Starter vitamin supplement (amount per kg of premix): Vit. A 2,916.67 IU; Vit. D3 583.33 IU; Vit.E 8,750.00 mg; Vit. K3 433.33 mg; Vit. B1 408.33 mg; Vit. B2 1,333.33 mg, Vit.

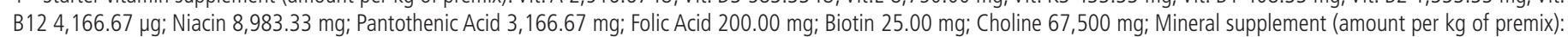
Iron 12,600.00 mg; Copper 3,072.00 mg; lodine 248.00 mg; Zinc 12,600.00 mg; Manganese 15,004.00 mg; Selenium 61.200 mg; Cobalt $50.400 \mathrm{mg}$.

2 - Grower vitamin supplement (Amount per kg of premix):Vit. A 2,250.000 IU/kg;Vit. D3 450,000 IU/kg;Vit. E 7,000 IU/kg; Vit. K3 418 mg/kg; Vit. B1 300 mg/kg; Vit. B2 1,000 mg/ kg, Vit. B12 3,000 mcg/kg; Niacin 7,000 mg/kg; Pantothenic acid 2,500 mg/kg; Folic Acid 140 mg/kg; Biotin 14 mg/kg; Mineral supplement(amount per kg of premix):Iron 12.5 g/kg; Copper 3,000 mg/kg; lodine 250 mg/kg; Zinc $12.5 \mathrm{~g} / \mathrm{kg}$; Manganese $15 \mathrm{~g} / \mathrm{kg}$; Selenium $75 \mathrm{mg} / \mathrm{kg}$; Cobalt $50 \mathrm{mg} / \mathrm{kg}$.

3 - L-Valine $98 \%$ addition in substitution of inert material (kaolin), according to the digestible valine levels in diet.

the myofibers and stored in liquid nitrogen. Next, the samples were transferred to cryostat chamber (Leica CM1850, Leica Microsystems GmbH, Wetzlar, Germany) at $-23^{\circ} \mathrm{C}$, where they remained for 40 min for thermal adaptation. Serial cryostat sections (10$\mu \mathrm{m} ;-20^{\circ} \mathrm{C}$ ) were made and captured with glass slides for histology (Pullen, 1977). Slides were stained with hematoxylin and eosin, and analyzed under a light microscope at 10Xmagnification, coupled to a digital camera attached. Ten images were captured per bird and the obtained images were analyzed using the software Motic $($ Images. All fibers were measured, using the small fiber diameter measuring method, according to Dubowitz \& Brooke (1973).

Data were submitted to analysis of variance. The F-test $(p<0.05)$ was applied to the compare two treatments, the control positive $\left(C_{+}\right)$treatment and the recommended TID Val levels in the treatments with reduced crude protein $1.009 \%$ in the pre-starter phase; $0.904 \%$ in the starter phase and $0.815 \%$ in the grower phase, separately in each phase). The data obtained with five digestible valine levels in the reduced $C P$ diet were also submitted to analysis of regression. A significance level of $p \leq 0.05$ was adopted. The statistical 
Nascimento GR, Murakami AE, Ospina-Rojas IC, Diaz-Vargas M, Picoli KP, Garcia RG

analyses were carried out using the software Statistical and Genetic Analysis System (SAEG, 2005).

\section{RESULTS AND DISCUSSION}

In the pre-starter phase (Experiment I), dietary TID Val levels had a quadratic effect $(p \leq 0.05)$ on weight gain and feed conversion ratio, with the highest weight gain estimated at $1.013 \%$ and the best feed conversion ratio at $1.028 \%$ TID Val level.

Birds fed the reduced-protein diet with $1.009 \%$ TID Val presented higher feed intake $(p \leq 0.05)$ and higher weight gain $(p \leq 0.05)$ compared with those fed the $C+$ diet, containing the same TID Val level, during the prestarter phase (Table 2). The higher feed intake observed
Digestible Valine Requirements in Low-Protein Diets for Broilers Chicks

in treatments with reduced protein may be explained by the supplementation of industrial amino acids, which may have caused an excess of essential amino acids, stimulating feed intake in order to compensate a possible deficiency of nitrogen for the synthesis of non-essential amino acids.

There were no effects of the evaluated TID Val levels ( $p>0.05)$ on feed intake or weight gain in the starter phase (Experiment II) and grower phase (Experiment III). However, in both phases, there was a quadratic effect $(p \leq 0.05)$ of TID Val levels on feed conversion ratio, with the best levels estimated at $0.905 \%$ and $0.853 \%$ for the starter and grower phases, respectively. The best estimated level for the starter phase $(0.905 \%$ of TID Val) is close to that recommended by Rostagno

Table 2 - Effect of dietary TID Val levels on broiler performance from 1 to 8 (Exp I), 9 to 21 (Exp II) and 21 to 42 days (Exp III).

\begin{tabular}{|c|c|c|c|}
\hline TID Valine (\%) & Feed intake (g/bird) & Weight gain (g/bird) & Feed conversion ratio \\
\hline \multicolumn{4}{|l|}{1 to 8 days } \\
\hline$C+$ & $135.561 \pm 4.44$ & $112.740 \pm 3.02$ & $1.202 \pm 0.03$ \\
\hline 0.866 & $141.332 \pm 4.37$ & $109.067 \pm 3.94$ & $1.296 \pm 0.06$ \\
\hline 0.935 & $137.919 \pm 5.75$ & $110.285 \pm 4.19$ & $1.250 \pm 0.05$ \\
\hline 1.009 & $138.680 \pm 5.75$ & $114.875 \pm 1.97$ & $1.207 \pm 0.06$ \\
\hline 1.084 & $139.101 \pm 7.14$ & $114.001 \pm 6.75$ & $1.221 \pm 0.05$ \\
\hline 1.158 & $135.655 \pm 4.12$ & $107.626 \pm 1.46$ & $1.268 \pm 0.01$ \\
\hline$p$-value & 0.017 & 0.005 & 0.001 \\
\hline Regression & NS & ${ }^{1} \mathrm{Q}=1.013$ & ${ }^{2} \mathrm{Q}=1.028$ \\
\hline$C+$ vs. 1.009 & $\leq 0.001$ & $\leq 0.001$ & NS \\
\hline $\mathrm{CV}(\%)$ & 2.78 & 3.49 & 3.01 \\
\hline \multicolumn{4}{|l|}{9 to 21 days } \\
\hline$C+$ & $924.378 \pm 21.74$ & $622.208 \pm 16.22$ & $1.486 \pm 0.01$ \\
\hline 0.755 & $909.304 \pm 9.43$ & $566.075 \pm 6.40$ & $1.606 \pm 0.01$ \\
\hline 0.830 & $895.261 \pm 24.37$ & $564.757 \pm 7.60$ & $1.585 \pm 0.03$ \\
\hline 0.904 & $912.042 \pm 19.53$ & $584.990 \pm 14.59$ & $1.562 \pm 0.03$ \\
\hline 0.979 & $920.325 \pm 15.06$ & $579.136 \pm 6.18$ & $1.588 \pm 0.03$ \\
\hline 1.053 & $922.602 \pm 14.24$ & $575.643 \pm 4.86$ & $1.603 \pm 0.03$ \\
\hline p-value & 0.315 & 0.234 & 0.034 \\
\hline Regression & NS & NS & ${ }^{3} \mathrm{Q}=0.905$ \\
\hline$C+$ vs. 0.904 & NS & NS & $\leq 0.001$ \\
\hline $\mathrm{CV}(\%)$ & 4.81 & 4.33 & 3.69 \\
\hline \multicolumn{4}{|l|}{21 to 42 days } \\
\hline$C_{+}$ & $3913 \pm 0.02$ & $1951 \pm 0.02$ & $2.006 \pm 0.02$ \\
\hline 0.695 & $3969 \pm 0.04$ & $1861 \pm 0.03$ & $2.133 \pm 0.02$ \\
\hline 0.755 & $3961 \pm 0.02$ & $1899 \pm 0.02$ & $2.087 \pm 0.02$ \\
\hline 0.815 & $4034 \pm 0.03$ & $1973 \pm 0.02$ & $2.045 \pm 0.01$ \\
\hline 0.875 & $3934 \pm 0.01$ & $1913 \pm 0.01$ & $2.056 \pm 0.01$ \\
\hline 0.935 & $3952 \pm 0.02$ & $1910 \pm 0.01$ & $2.070 \pm 0.01$ \\
\hline$p$-value & 0.451 & 0.112 & 0.007 \\
\hline Regression & NS & NS & ${ }^{4} \mathrm{Q}=0.853$ \\
\hline$C+$ vs. 0.815 & NS & NS & $\leq 0,001$ \\
\hline CV (\%) & 2.27 & 3.25 & 2.86 \\
\hline
\end{tabular}

NS - Not Significant; Q -Quadratic effect.

${ }^{1} Y=176+572.57 \mathrm{TID} \mathrm{Val}-282.42 \mathrm{TID} \mathrm{Val}^{2}\left(\mathrm{R}^{2}=0.79\right) . P=0.014$

${ }^{2} Y=4.715-6.809 \mathrm{TID} \mathrm{Val}+3.3085 \mathrm{TID} \mathrm{Val}^{2}\left(R^{2}=0.97\right) . P=0.001 ;$

${ }^{3} \mathrm{Y}=2.848-2.821 \mathrm{TID} \mathrm{Val}+1.558 \mathrm{TID} \mathrm{Val}^{2}\left(R^{2}=0.85\right) . P=0.021 ;$

${ }^{4 Y}=4.567-5.587 \mathrm{TID} \mathrm{Val}+3.432 \mathrm{TID} \mathrm{Val}^{2}\left(R^{2}=0.97\right), P=0.001$. 
Nascimento GR, Murakami AE, Ospina-Rojas IC, Diaz-Vargas M, Picoli KP, Garcia RG

\section{Digestible Valine Requirements in Low-Protein Diets for Broilers Chicks}

et al. (2011), of $0.904 \%$. The reduced protein in the diet not affect the recommended TID Val level, possibly due the lower digestible leucine (TID Leu) level and to the supplementation of isoleucine in the RP diet in the starter phase (Table 1). High dietary leucine level increases the requirements of valine and isoleucine (D'Mello \& Lewis, 1970), and therefore, the lower TID Leu level did not require valine supplementation.

The TID Val levels estimated for the grower phase (21 to 42 days) was $0.853 \%$ for feed conversion ratio in the $16.5 \%$ crude protein diet, differently that recommended by Tavernari et al. (2013), who estimated $0.790 \%$ TID Valin diets with $18.2 \%$ CP for 30- to 42-d-old broilers. Despite the small difference in crude protein levels (16.5 and 18.2\%), the difference in the requirement estimates is probably due to the inclusion of animal byproducts in the study of Tavernari et al. (2013), which reduces valine requirement.

In the starter and grower phases, the $\mathrm{C}+$ diet promoted better feed conversion ratio $(p \leq 0.05)$ when compared with those fed the reduced-CP diet with same TID Val level (Table2), which may be explained by the difference in essential to nonessential ratios (EAA:NEAA). In the starter phase, the control diet had a ratio of $45: 55$ and was increased to $48: 52$ in the reduced-CP diet, while the grower phase ratio was 45:55 to 49:51 when the dietary protein was reduced in 2 p.p. According to Jiang et al. (2005), the EAA:NEAA recommended ratio is 46:54 in reduced-protein diets with for broilers. Corzo et al. (2011) evaluated valine supplementation to conventional or reduced-protein diets $(17.6 \% \mathrm{CP})$ fed to 28 - to 42 -d-old broilers found worse feed conversion ration when birds fed the low CP diet, and attributed this result to arginine and isoleucine deficiency. Considering that in the present study, arginine and isoleucine levels did not differ between the experimental diets, the worse feed conversion ratio may be attributed to inadequate EAA:NEAA ratios. The reduced-CP diet contained less nonspecific nitrogen for AANE synthesis, directing AAE for the synthesis of AANE, which may cause AAE deficiency, therefore limiting protein synthesis (Heger, 2003).

There was no effect $(p>0.05)$ of the dietary treatments on carcass and parts yields (back, thighs, drumsticks and wings) or abdominal fat percentage of 42-d-old broilers (Table 3) Dozier et al. (2012) found similar results, when feeding broilers diets supplemented with valine from 4 to 6 weeks of age. However, there was a quadratic effect $(p \leq 0.05)$ of TID Val levels on breast yield, with the highest value estimated at $0.826 \%$ of TID Val (Figure 5). Tavernari et al. (2013) estimated $0.730 \%$ TID Val for 30- to 43-old broilers fed diets containing animal by products in order to obtain maximum breast yield. The higher estimated level of TID Val the present $(0.826 \%)$ compared with that of Tavernari et al. (2013) may be ascribed to the dietary inclusion of only plant-derived products, which may increase valine requirements in reduced-protein diets (Berres et al., 2010).

Based on the result presented on Table 3, the TID Val level required to maximize breast yield $(0.826 \%)$ was lower than that required to optimize feed conversion ratio $(0.853 \%)$ in 21 - to 42 -d-old. Valine is a branchedchain amino acid that is mainly metabolized in the skeletal muscle, and it is responsible for body protein balance (Rogero \& Tirapegui, 2008). Considering previous findings (Berres et al., 2011; Tavernari et al., 2013), it may be concluded that valine requirements for protein accretion are lower than those required for feed conversion in broilers. Therefore, the TID Val levels estimated for feed conversion ratio are recommended to be applied in broiler feed formulation, as they are

Table 3 - Effect of dietary TID Val levels on carcass and parts yields, and abdominal fat percentage of 42-d-old broilers.

\begin{tabular}{|c|c|c|c|c|c|c|}
\hline TID Valine (\%) & Carcass (\%) & Breast (\%) & Thigh and drumstick (\%) & Wing (\%) & $\operatorname{Back}(\%)$ & Abdominal Fat (\%) \\
\hline $\mathrm{C}+$ & 71.79 & 40.32 & 31.08 & 10.41 & 18.25 & 1.79 \\
\hline 0.695 & 72.13 & 39.11 & 30.92 & 10.48 & 18.59 & 2.27 \\
\hline 0.755 & 71.43 & 39.67 & 31.07 & 10.63 & 18.57 & 2.91 \\
\hline 0.815 & 72.31 & 39.94 & 31.43 & 10.28 & 18.24 & 2.40 \\
\hline 0.875 & 72.17 & 39.57 & 31.54 & 10.29 & 18.39 & 2.13 \\
\hline 0.935 & 71.66 & 39.42 & 31.15 & 10.23 & 19.29 & 2.74 \\
\hline SEM & 0.43 & 0.48 & 0.35 & 0.20 & 0.35 & 0.16 \\
\hline$p$-value & 0.215 & 0.021 & 0.335 & 0.416 & 0.115 & 0.084 \\
\hline Regression & NS & ${ }^{1} \mathrm{Q}=0.826$ & NS & NS & NS & NS \\
\hline$C+$ vs. 0.815 & NS & NS & NS & NS & NS & NS \\
\hline $\mathrm{CV}(\%)$ & 2.24 & 4.39 & 4.09 & 7.11 & 7.58 & 23.78 \\
\hline
\end{tabular}

NS - Not significant; Q - quadratic effect $(p<0.05)$.

$1 Y=11.981+67.49$ TID Val- $40.873 \operatorname{TID~Val}^{2}\left(R^{2}=0.94\right) . P=0.002$ 
Nascimento GR, Murakami AE, Ospina-Rojas IC, Diaz-Vargas M, Picoli KP, Garcia RG

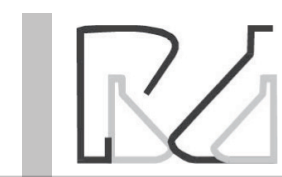

Digestible Valine Requirements in Low-Protein Diets for Broilers Chicks higher than those estimated for other production parameters.

The muscle fiber diameter of the pectoralis major in 42-d-old broilers linearly increased $(p \leq 0.05)$ with dietary TID Val values (Table 4). Increasing dietary Val content stimulates muscle development, increasing muscle fiber diameter due to the deposition of myofibril proteins (Petracci \& Cavani, 2012), which contributed to increase the breast yield of the broilers fed TID Val levels higher than $0.755 \%$.

Table 4 - Effect of dietary TID Val levels on the diameter of the muscle fiber of the pectoralis major in 42-d-old broilers.

\begin{tabular}{ll}
\hline TID Valine $(\%)$ & Muscle diameter of the Pectoralis major $(\mu \mathrm{m})$ \\
\hline $\mathrm{C}+$ & $49.874 \pm 0.266$ \\
\hline 0.695 & $45.875 \pm 0.241$ \\
0.755 & $46.396 \pm 0.249$ \\
0.815 & $46.339 \pm 0.277$ \\
0.875 & $47.711 \pm 0.251$ \\
0.935 & $49.595 \pm 0.299$ \\
\hline p-value & 0.001 \\
Regression & $1 \mathrm{~L}$ \\
$\mathrm{C}+$ vs. 0.815 & $\leq 0.001$ \\
$\mathrm{CV}(\%)$ & 19.21 \\
\hline
\end{tabular}

$L-$ Linear effect $(p<0.05)$.

${ }^{1} Y=35.291+14.592 \times\left(R^{2}=0.84\right) \cdot p=0.015$.

The broilers fed the reduced-protein with $0.815 \%$ of TID Val presented lower $(p \leq 0.05)$ muscle fiber diameter of the pectoralis major compared with to birds fed the $\mathrm{C}+$ diet in the grower phase (Table 4). This effect may be related to the imbalance between $A A E$ and $A A N E$, as part of the AAE may have been used to synthesize AANE, reducing AAE availability for myofibril protein deposition.

\section{CONCLUSION}

The recommended digestible valine levels to achieve maximum feed conversion ratio in broilers during pre-starter, starter, and grower phases are $1.028 \%, 0.905 \%$, and $0.853 \%$, respectively, whereas for maximum breast yield, it is $0.826 \%$ for broilers between 21 and 42 days of age.

Feeding low-protein diets during the grower phase reduced muscle fiber diameter, but did not affect carcass and parts yields or abdominal fat percentage in 42-d-old broilers.

\section{ACKNOWLEDGEMENTS}

The authors would like to thank National Council for Scientific and Technological Development (CNPq) for financing the research.

\section{REFERENCES}

Berres J, Vieira SL, Kidd MT, Taschetto D, Freitas DM, Barros R, e al. Supplementing L-valine and L-isoleucine in low-protein corn and soybean meal all-vegetable diets for broilers. Journal Applied Poultry Research 2010;19:373-379.

Berres J, Vieira SL, Favero A, Freitas DM, Peña JEM, Nogueira ET. Digestible valine requeriments in high protein diets for broilers from twentyone to forty-two days of age. Animal Feed Science and Technology 2011;165:120-124.

Campos AMA, Rostagno HS, Nogueira ET, Albino LFT, Pereira JPL, Maia RC. Atualização da proteína ideal para frangos de corte: arginina, isoleucina, valina e triptofano. Revista Brasileira de Zootecnia 2012;41(2):326-332.

Corzo A, Dozier III WA, Loar II RE, Kidd MT, Tillman PB. Dietary limitation of isoleucine and valine in diets based on maize, soybean meal, and meat and bone meal for broiler chickens. British Poultry Science 2010;51(4):558:563.

Corzo A, Dozier III WA, Meija L, Zumwalt CD, Kidd MT, Timan PB. Nutritional feasibility of I-valine inclusion in commercial broiler diets. Journal Applied Poultry Reseach 2011;20(3):284-290.

Corzo A, Kidd MT, Dozier III WA, Vieira SL. Marginality and needs of dietary valine for broilers fed certain all-vegetable diets. Journal Applied Poultry Research 2007;16:546-554.

Dozier III WA, Tillman PB, Usry J. Interactive effects of digestible valine and isoleucine to lysine ratios provided to male broilers from 4 to 6 weeks of age. Journal Applied Poultry Reseach 2012;21:838-848.

Duarte KF, Junqueira OM, Domingues CHF, Filardi RS, Borges LL, Praes MFFM. Digestible valine requirements for broilers from 22 and 42 days old. Acta Scientiarum. Animal Sciences 2014;36 (2):151-156

Dubowitz V, Brooke M. Muscle biopsey: a modern approach. London: Sauders; 1973.

D'Mello JPF. Amino acid in animal farms. Wallingford: CABI; 2003.

D’Mello JPF, Lewis D. Amino acid interactions in chicks nutrition. 2. Interrelationships between leucine, isoleucine and valine. British Poultry Science 1970;16(6):607-615.

Heger J. Essential to no-essential amino acid ratios. In: D’Mello JPF, editor. Amino acids in farm animal nutrition. Wallingford: CAB International; 2003. p.103-124.

Jiang Q, Waldroup PW, Fritts CA. Improving the utilization of diets low in crude protein for broiler chicken, 1. Evaluation of specific amino acid supplementation to diets low in crude protein. International Journal Poultry Science 2005;4:115-122.

Petracci M, Cavani C. Muscle growth and poultry meat quality. Nutrients 2012;4(1):1-12.

Pullen $\mathrm{AH}$. The distribution and relative size of fiber type in the extensor digitorum longus and soleus muscles of the adult rat. Journal of Anatomy 1977;123(2):467-86.

Rogero MM, Tirapegui J. Aspectos atuais sobre aminoácidos de cadeia ramificada e exercício físico. Revista Brasileira de Ciências Farmacêuticas 2008;44(4):563-575.

Rostagno HS, Albino LFT, Donzele JL. Tabelas brasileiras para aves e suínos: composição de alimentos e exigências nutricionais. $3^{a}$ ed. Viçosa: UFV; 2011.

SAEG. Sistema para análises estatísticas, Versão 9.0. Viçosa: Fundação Arthur Bernardes/UFV; 2005.

Tavernari FC, Lelis GR, Vieira RA, Rostagno HS, Albino LF, Oliveira Neto AR Valine needs in starting and growing cobb 500 broilers. Poultry Science 2013;92(1):151-157.

Thornton SA, Corzo A, Pharr GT, Dozier WA, Miles DM, Kidd MT. Valine requirements for immune and growth responses in broilers from 3 to 6 weeks of age. British Poultry Science 2006;47(2):190-199. 